\title{
The International as National: The Role of International Cultural Policy in the Construction of Dutch Design as Conceptual
}

Today, the idea has become dominant that Dutch Design is conceptual, minimalist, handmade, and produced as one-off or in small-series. Here, the term Dutch Design is used as a discursive construction (Foucault 2011), and refers to the artefacts construed as 'Dutch' and as 'Design' by the eponymous discourse. This discourse 'began'-in Edward Said's (2003) sense that it gained density, coherence and regularity -in the wake of Droog Design's success in the 1990s. In this discourse, authors frequently explain the reason why Dutch Design possesses this particular set of characteristics by pointing to 'Dutch culture', which they define in terms of the Dutch Golden Age: Calvinism, the artificially constructed landscape, the political Polder Model, entrepreneurship, and a shortage of resources (Taylor 2010). This suggests not only that Dutch culture is static, but also that the Golden Age remains the main source of explanation for events five centuries later. This essentialist conception of culture ignores the globalised flows of people, ideas and goods, and as such obscures more recent and relevant factors involved in the construction of Dutch Design. Following recent constructivist approaches to Dutch Design (De Rijk 2010; Taylor 2010; Ozorio de Almeida Meroz \& Griffin 2012; Gimeno Martínez, Ozorio de Almeida Meroz \& Serulus 2013), this paper traces the actor-networks (Latour 2005) contributing to the production of the exhibition Design from the Netherlands (1980), which historians (Simon Thomas 2008; Hompe 2011) concur is the first discursive construction of Dutch Design as conceptual. Based on archival research and oral history, this paper argues that rather than the outcome of typical Dutch culture, the association of Dutch Design and conceptualism is instead first given as the result of the restructuring of policies concerning the international promotion of design in the 1970 .

dutch design, conceptual design, actor-network-theory, design policy, international cultural policy

\section{Introduction: Dutch Design as Modern}

Between 1949 and 1975, the industrial design promoted internationally as typical of the Netherlands was in line with functionalist modernism. During this period, the Design Council of the Netherlands was officially responsible for design promotion domestically and abroad.' Supported by the government in the context of post-war industrialisation politics, its task was to help improve the Netherlands' economic position by enhancing the quality of Dutch manufacture (Huygen 1987). Through its showroom in Amsterdam,

\footnotetext{
'The Council has a complex institutional history marked by many name changes; see Huygen 1987. For the sake of brevity, here it will be referred to simply as 'Council'
} 
international exhibitions and publications, the Council endorsed "reliable, simple and inexpensive" design, which it promoted as the "recognised qualities of the typical Dutch product" (Simon Thomas 2008: 141). Through this discourse, the Council construed Dutch design as modern. How did it happen that a few years later design from the Netherlands became associated with conceptualism?

\section{The International Promotion of Design from the Netherlands}

In time, one of the Council's main patrons, the Ministry of Economic Affairs, started seeing the Council's emphasis on 'good' design as counter-productive to economic development (Huygen 1987). Hence, the Ministry discontinued the organization's subsidies, leading to the Council's closure in 1975 (ibid). Subsequently, design was left without an officially recognized national representative body until the establishment of the Netherlands Foundation for Industrial Design in 1985.

In the interim, this institutional vacuum was partly filled by the Visual Arts Office for Abroad (Bureau Beeldende Kunst Buitenland, BBKB), which inadvertently took over the role of representing Dutch design abroad. The BBKB was founded in 1974 with the task to expand the appreciation of Dutch culture abroad by organizing internationally traveling exhibitions on Dutch modern art (Kuyvenhoven 2007). It was part of the government's attempt at increasing the coherence of its International Cultural Policy (ICP), which was marred by competition between the two main responsible ministries, Foreign Affairs and Culture. Historically, the former was interested in promoting 'typical Dutch culture' as part of its 'Holland Promotion' programme for political-economic ends, while the former viewed the internationalization of Dutch art as necessary to the development of the cultural field in the Netherlands since culture is transnational (Delhaye 2009; Minnaert 2009). Creating one organ would, hopefully, lead to greater effectiveness in state presentations of Dutch culture abroad.

Although the BBKB was part of a complex bureaucratic and financial circuit between the above-mentioned ministries, it subscribed to the cultural argument. First, as a sub-division of the Ministry of Culture, the BBKB-both literally and figuratively-shared its premises. Second, its staff came from the cultural field: both the director Gijs van Tuyl and the applied arts curator Evert Rodrigo had held the same functions at the Stedelijk Museum Amsterdam-the "temple of modern art" (Boot 2014: 44). Consequently, the BBKB shared the Stedelijk's criteria when selecting the type of art to promote: modern and internationally oriented (Van Tuyl 2013).

Hence, there was a friction between Foreign Affairs' and BBKB's goals in the promotion of Dutch culture abroad, which Van Tuyl tried to solve by translating the diplomatic imperatives into BBKB's interests. First, while ICP sought to promote the "original aspects of Dutch culture" (Ministry of Foreign Affairs 1970: 2), the BBKB selected art made in the Netherlands not due to its 'national character', but on the contrary, due to the extent it resonated with international artistic currents. Unlike today's nation branding strategies, Van Tuyl believed that to successfully "put Dutch art in an international context" it was necessary not to "stretch so much the national characteristics [...] [but] on the contrary [...] [to] stretch the common denominator" (ibid). Hence, he "look[ed] for art which already has some kind of relation or some kind of international character"-which at that time meant conceptual, minimalist, modern art (ibid) (Fig. 1). Second, while, in the words of Rodrigo (2011), "the objective of this Office [the BBKB], when I say it just very bluntly, was to push contemporary Dutch art into major spots in the world," as Van Tuyl (2013) 


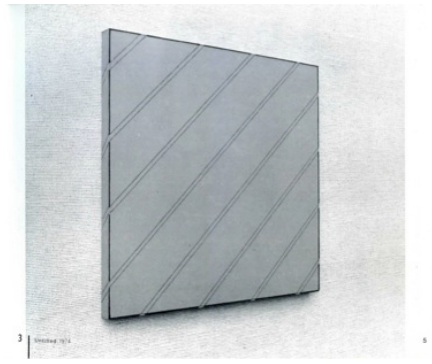

explains, "that's completely different from [the] political agenda [...]. The queen goes to, I don't know Kenya, and then the exhibition went along. [...] [Foreign Affairs] needed an exhibition in Zambia or in Thailand or Indonesia and sometimes it was not very helpful to bring an exhibition there for art." So BBKB "used the channels" (Van Tuyl 2013) of ICP to disseminate its own agenda. As we will see, BBKB's institutional structure played a key role in forging the association between Dutch and conceptual design.

\section{Design from the Netherlands, the Making-of}

Circa 1979 Joep Kempen, a Foreign Affairs cultural attaché stationed at the consulate in Bonn, developed the idea to mount an exhibition on Dutch design at the Design Center Stuttgart as part of a Dutch cultural festival due to take place in that city during the summer of 1980 (Van Tuyl 2013). Although design was "only a small part" of BBKB's work, one of its most successful shows had been the 1974 traveling exhibition curated by jeweller-designer Gijs Bakker, Contemporary Jewellery from the Netherlands (jewellry was then also considered design) (ibid). Van Tuyl had become acquainted with Bakker's work at Art \& Project, the internationally renowned "high gallery of conceptual art" in Amsterdam (ibid). Although strictly not art, Van Tuyl recognized in Dutch conceptual jewellery the same sensibility and visual language present in conceptual art. Hence, Dutch conceptual jewellery perfectly fit the diplomatic and cultural agendas: it was both particular and resonated with international artistic developments. According to Van Tuyl (2013), the success of the jewellery exhibition "was really an eye opener" for BBKB who "had no experience curating design exhibitions" and "also for Foreign Affairs because it [jewellery/design] was something fresh, something Dutch and not provocative" (ibid). On the basis of this experience, the different actors accepted Kempen's proposal.

Seeking to emulate the jewellery show's success, Van Tuyl invited Bakker to curate the design exhibition. Bakker accepted as it afforded him the opportunity to disseminate his design views internationally (Hompe 2011). He argued that while modern design's functionalist formalism was originally driven by democratic ideals, by the $1960 \mathrm{~s}$ it had degenerated into another style at the service of capitalism (Bakker 1984). To him, the problem was that modern design's aesthetics followed from the logic of profit maximization rather than from its cultural values (Ober 1979). To restore design's social relevance, the designer, working independently from industry, should develop clear concepts regarding design's functions from the user's perspective. Design's aesthetics should follow from this reconceptualization of its function; hence Bakker's motto "form follows concept" (1984).

Bakker identified a number of designers in the Netherlands working along similar lines. For the exhibition Bakker selected designers "who work in a fundamental fashion" (1980: 4):
Figure 1.

Ben Akkerman, Untitled (1974) [Oil/canvas, $60 \times 60 \mathrm{~cm}]$. Source: BBKB 1975: 5. BBKB promoted Dutch modern, minimalist art due to its international resonance. For example, in 1975 it toured the exhibition Elementary Forms of Contemporary Painting and Drawing in the Netherlands, which showed the "[w] ]ork of thirteen Dutch artists who [...] might be labelled 'fundamental painters"' (BBKB 1978: 39). According to the catalogue, their work has "a relationship with conceptual art" (BBKB 1975: 2). 
theme 5

society

Figure 2.

Gijs Bakker, Strip

Chair (1974)

[laminated wood, $77 \times 44 \times 53 \mathrm{~cm}]$. Fundamentalist design resonated clearly with the modern, minimalist art that BBKB was promoting. Source: Bakker 1980: 11 strand 1

design policies
Objects such as Bakker's Strip Chair (Fig. 2), Reinder van Tijen's water pumps and cement mixers using recycled materials for the 'Third World' and Henk Lampe's sculptural furniture can be clearly characterized as 'fundamental designs'. Yet others, such as Philips' home-appliances seem at odds with the curatorial premises.

Nevertheless, the selection makes sense in light of BBKB's hybrid institutional structure. For BBKB, "Bakker's approach fit in very well with what the Office was doing already in promoting contemporary art. It's 'arty', it's design-but it's art. [...] [T] his selection was acceptable because it had a lot of the feeling of handmade, three-dimensional paintings, or sculptural works" (Rodrigo 2011). However, the exhibition also had to fit Foreign Affairs' promotional purposes. With an internationally touring exhibition titled Design from the Netherlands it was unthinkable to exclude the country's best-known design multinational (Hompe 2011). Rodrigo: "Philips was just there because they are a very well known name internationally" (2011).

After opening at the Design Center Stuttgart, the BBKB toured the exhibition until 1985 through its network of prestigious art institutions in Europe and beyond. Judging by the press clippings kept at BBKB's archives, the public and press unproblematically accepted the exhibition's discursive construction of Dutch design as conceptual.

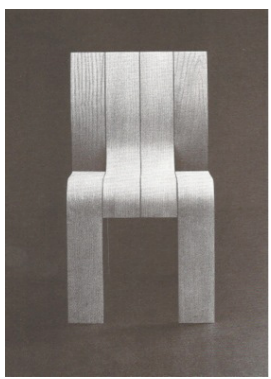

\section{Conclusion: The International as National}

Bakker's vision of Fundamentalist design is a proto-version of what today is known as Dutch conceptual design. As the analysis above reveals, the institutional particularities of the policies relating to the international promotion of design had a significant part in the identification between Dutch and conceptual design. With the restructuring of ICP in the 1970 s, the BBKB took on the role of representing Dutch design abroad. It selected a type 
of design that fit in its policy of promoting Dutch minimalist, conceptual modern art due to its international resonance. Hence, rather than selecting Fundamentalist design because it represented the national culture, the BBKB disseminated it as Dutch precisely because of its international character. Indeed, Bakker developed the notion of Fundamentalist design within the international circuit of minimalist, conceptual modern art. As this paper shows, national design histories are deeply entangled in transnational developments, and as such, it is fruitful to examine their formations in relation to the global networks in which they evolved.

\section{References}

Bakker, G. (1980) Design from the Netherlands/Design aus den Niederlanden, Amsterdam: Visual Arts Office for Abroad of the Ministry of Culture, Recreation and Social Welfare. Bakker, G. (1984) 'Form Follows Concept', Items, vol. 3 no. 13, pp. 2-3.

BBKB archives, Cultural Heritage Agency, Rijswijk.

BBKB (1975) Elementary Forms of Contemporary Painting and Drawing in the Netherlands, Amsterdam: Visual Arts Office for Abroad of the Ministry of Culture, Recreation and Social Welfare.

BBKB (1978) 'The Visual Collections of the Visual Arts Office for Abroad', DA+AT, no. 3 , May, p. 39.

Boot, M. (2014) De Show van Gijs + Emmy: Mode- en Sieraadontwerpen. The Gijs + Emmy Spectacle: Fashion and Jewellery Design. Gijs Bakker + Emmy van Leersum, 1967-1972, Rotterdam: NAlo1o Publishers.

Delhaye, C. (2009) 'Van Toefje op de Taart naar Basisingrediënt: Internationaal Cultuurbeleid in Tijden van Globalisering', Boekman, vol. 21, no. 80, autumn, pp. 84-88. Design Council of the Netherlands (1973?) Dutch Design for the Public Sector I. [poster] BBKB archives, Cultural Heritage Agency, Rijswijk.

Foucault, M. (2011) The Archeology of Knowledge, London/New York: Routledge. Gimeno Martínez, J., Ozorio de Almeida Meroz, J. and Serulus, K. (2013) 'Localizing Design/Designing Location: Creative Cities in the Low Countries', Dutch Crossing, vol. 37 , no. 3, pp. 274-292.

Hompe, R. (2011) 'Een Veld Witgeschilderde Tulpen: Exposities en het Designdiscours in de Jaren Tachtig,' Designgeschidenis Nederland [online] Available at: http://www. designhistory.nl/2011/een-veld-witgeschilderde-tulpen-exposities-en-het-designdiscoursin-de-jaren-tachtig/ [Accessed 12 March 2013].

Huygen, F. (1984) 'Tussen Ambacht en Industrie', Items, vol. 3, no. 14, pp. 4-24. Huygen, F. (1987) 'Fighting a Losing Battle?', in Staal, G. and Wolters, H. (ed.) Holland in Vorm: Dutch Design 1945-1987, Amsterdam/'s-Gravenhage: Stedelijk Museum/Stichting Holland in Vorm.

Kuyvenhoven, F. (2007) De Staat Koopt Kunst: De Geschiedenis Van De Collectie 20steeeuwse Kunst Van Het Ministerie Van OCW 1932-1992, Amsterdam/Leiden: Instituut Collectie Nederland/Primavera Pers.

Latour, B. (2005) Reassembling the Social: An Introduction to Actor-Network-Theory, Oxford: Oxford University Press.

Ministry of Foreign Affairs (1970) Nota Betreffende de Internationale Culturele Betrekkingen, Tweede Kamer zitting 1970-1971, 10916.

Minnaert, T. (2009) 'Drang naar Samenhang: Het Internationaal Cultuurbeleid van Nederland', Boekman, vol. 21, no. 80, autumn, pp. 6-13.

Ober, J. (1979) 'Gijs Bakker: Furniture and Lighting Design', DA+AT, no. 5, June, pp. 27-30. Ozorio de Almeida Meroz, J. and Griffin, R. (2012) 'Open Design: A History of the Construction of a Dutch Idea', The Design Journal, vol. 15, no. 4, pp. 405-422.

De Rijk, T. (2010) 'So-called Craft: The Formative Years of Droog Design, 1992-1998', The 
theme 5

society strand 1

design policies

Journal of Modern Craft, vol. 3, no. 2, July, pp. 161-178.

Rodrigo, E. (2011) [interview with the author, Amsterdam, 17 August 2011].

Said, E. W. (2003) Orientalism, London: Penguin.

Simon Thomas, M. (2008) Dutch Design: A History, London: Reaktion Books.

Taylor, D. (2010) 'Mountain Climbing in Holland: Writing Dutchness Into the Discourse', in Gimeno Martínez, J. and Floré, F. (ed.) Design and Craft: A History of Convergences and Divergences, Weteren: Universa Press.

Van Tuyl, G. (2013) [interview with the author, Amsterdam, 14 October 2013]. 